\title{
Galectin-1 and galectin-3 expression in equine mesenchymal stromal cells (MSCs), synovial fibroblasts and chondrocytes, and the effect of inflammation on MSC motility
}

Heidi L. Reesink ${ }^{1 *}$, Ryan M. Sutton ${ }^{1}$, Carolyn R. Shurer ${ }^{2}$, Ryan P. Peterson ${ }^{1}$, Julie S. Tan ${ }^{1}$, Jin Su', Matthew J. Paszek ${ }^{2}$ and Alan J. Nixon ${ }^{1 *}$

\begin{abstract}
Background: Mesenchymal stromal cells (MSCs) can be used intra-articularly to quell inflammation and promote cartilage healing; however, mechanisms by which MSCs mitigate joint disease remain poorly understood. Galectins, a family of $\beta$-galactoside binding proteins, regulate inflammation, adhesion and cell migration in diverse cell types. Galectin-1 and galectin-3 are proposed to be important intra-articular modulators of inflammation in both osteoarthritis and rheumatoid arthritis. Here, we asked whether equine bone marrow-derived MSCs (BMSCs) express higher levels of galectin-1 and -3 relative to synovial fibroblasts and chondrocytes and if an inflammatory environment affects BMSC galectin expression and motility.

Methods: Equine galectin-1 and -3 gene expression was quantified using qRT-PCR in cultured BMSCs, synoviocytes and articular chondrocytes, in addition to synovial membrane and articular cartilage tissues. Galectin gene expression, protein expression, and protein secretion were measured in equine BMSCs following exposure to inflammatory cytokines (IL-1 5 and $10 \mathrm{ng} / \mathrm{mL}$, TNF- $\alpha 25$ and $50 \mathrm{ng} / \mathrm{mL}$, or LPS $0.1,1,10$ and $50 \mu \mathrm{g} / \mathrm{mL}$ ). BMSC focal adhesion formation was assessed using confocal microscopy, and BMSC motility was quantified in the presence of inflammatory cytokines (IL-1 $\beta$ or TNF-a) and the pan-galectin inhibitor $\beta$-lactose (100 and 200 mM).

Results: Equine BMSCs expressed 3-fold higher galectin-1 mRNA levels as compared to cultured synovial fibroblasts $(p=0.0005)$ and 30-fold higher galectin-1 $(p<0.0001)$ relative to cultured chondrocytes. BMSC galectin-1 mRNA expression was significantly increased as compared to carpal synovial membrane and articular cartilage tissues $(p<0.0001)$. IL-1 $\beta$ and TNF- $a$ treatments decreased BMSC galectin gene expression and impaired BMSC motility in dose-dependent fashion but did not alter galectin protein expression. $\beta$-lactose abrogated BMSC focal adhesion formation and inhibited BMSC motility.

Conclusions: Equine BMSCs constitutively express high levels of galectin-1 mRNA relative to other articular cell types, suggesting a possible mechanism for their intra-articular immunomodulatory properties. BMSC galectin expression and motility are impaired in an inflammatory environment, which may limit tissue repair properties following intra-articular administration. $\beta$-lactose-mediated galectin inhibition also impaired BMSC adhesion and motility. Further investigation into the effects of joint inflammation on BMSC function and the potential therapeutic effects of BMSC galectin expression in $\mathrm{OA}$ is warranted.
\end{abstract}

Keywords: Osteoarthritis, Adhesion, Migration, Horse, Stem cell, IL-1ß, TNF-a

\footnotetext{
*Correspondence: hlr42@cornell.edu; ajn1@cornell.edu

'Department of Clinical Sciences, College of Veterinary Medicine, Cornell

University, Ithaca, NY 14853, USA

Full list of author information is available at the end of the article
} 


\section{Background}

Joint trauma, inflammation and the subsequent development of osteoarthritis (OA) are common in both humans and horses. Joint inflammation is precipitated by the production of catabolic cytokines, such as interleukin-1 beta (IL-1 $\beta$ ) and tumor necrosis factor alpha (TNF- $\alpha$ ), in addition to immune cell infiltration. Mesenchymal stem cells (MSCs) were initially appealing as a cell source for the repair of articular cartilage and other musculoskeletal injuries due to their multilineage potential [1]. However, low rates of long-term survival, engraftment and differentiation in musculoskeletal tissues $[2,3]$ led to a failure to observe many of these properties. Thus, the paradigm for intra-articular MSCbased therapies has shifted from MSCs as tissue reparative cells to MSCs as immunomodulatory cells that modify the microenvironment to encourage tissue repair by endogenous tissue progenitor cells $[4,5]$. MSCs have been used intra-articularly to decrease joint inflammation and promote cartilage healing in both experimental animal models of OA $[3,6,7]$ and in human clinical trials $[8,9]$; however, the mechanisms by which MSCs perform these actions are poorly understood.

Various secreted molecules have been implicated in the anti-inflammatory and regenerative properties of stem cells, including prostaglandin $\mathrm{E}_{2}\left(\mathrm{PGE}_{2}\right)[4,10]$, indoleamine 2,3-dioxygenase (IDO) [11], interleukin-10 (IL-10) [4], tumor necrosis factor-inducible gene 6 (TSG-6) [12] and interleukin-1 receptor antagonist (IL1Ra) [13]. Recently, galectin-1 and galectin-3 have been proposed as potent mediators of MSC immunomodulatory properties [14-18] and MSC motility [19]. Human MSCs constitutively express galectins $-1,-3$ and $-8[15,20]$, with abundant expression of galectins- 1 and -3 in human umbilical cord blood-derived MSCs [16]. Both galectin-1 $[17,21,22]$ and galectin-3 $[14-17,21,23]$ appear to play a significant role in the ability of human MSCs to downregulate immune responses. Furthermore, galectin-1 has been shown to induce chondrogenic differentiation of MSCs from the bone marrow of rheumatoid arthritis patients [24]. However, galectin expression has not been previously investigated in equine MSCs.

Galectins comprise a family of more than $15 \beta$ galactoside binding proteins $[25,26]$. Galectin-1 possesses immunosuppressive and anti-inflammatory effects in many chronic inflammatory and autoimmune disorders, including graft-versus-host disease [27] and systemic lupus erythematosus [28]. Decreased galectin-1 and increased galectin-3 synovial fluid concentrations have been reported in human patients with OA [29], juvenile idiopathic arthritis [30, 31] and rheumatoid arthritis [32]. Galectin-3 has recently been shown to enhance cartilage boundary lubrication via interactions with lubricin/proteoglycan 4 [33]; however, galectin-3 gene expression is increased in OA cartilage as compared to normal cartilage [34]. Increased galectin-3 histochemical staining has also been observed in the synovial membrane and articular cartilage of arthritis patients [31, 35, 36]. In a collagen-induced arthritis model, gal-1 null (-/-) mice demonstrated an accelerated disease onset and more severe arthritis as compared to wild-type mice [37]. Both galectin-1 gene therapy and recombinant galectin-1 intra-articular administration abrogated clinical and histopathological signs of collageninduced arthritis in a murine model [38], suggesting that galectin-1 may be a possible therapeutic option for inflammatory arthritis. Beyond their role as immunomodulatory proteins, galectins also have diverse effects on cell adhesion, chemotaxis [39, 40] and migration [26].

Interestingly, many of the protagonists of MSC effects, including VEGF, IDO, $\mathrm{PGE}_{2}$ and galectin-9, are increased following exposure to inflammatory stimuli, including interferon gamma (IFN- $\Upsilon$ ), TNF- $\alpha$ and lipopolysaccharide (LPS) $[41,42]$. TNF- $\alpha$, one of the major inflammatory cytokines in OA, has been shown to enhance the regenerative potential and anti-inflammatory response in MSCs [41]. Priming of equine MSCs with TNF- $\alpha$ and IFN- $\Upsilon$ significantly upregulated COX-2, iNOS, IDO and IL-6 gene expression and adhesion-related genes, while downregulating migration-related genes [43]. Whereas exposure to high concentrations $(50 \mathrm{ng} / \mathrm{mL})$ of TNF- $\alpha$ and IFN- $\Upsilon$ negatively affected equine bone marrow-derived MSC (BMSC) viability and differentiation, lower concentrations ( $5 \mathrm{ng} / \mathrm{mL}$ ) did not demonstrate adverse effects [44]. To our knowledge, it is unknown how pro-inflammatory cytokines impact galectin expression, adhesion and motility in equine BMSCs. MSC adhesion to articular cartilage is critical for cartilage repair, and priming of MSCs with hyaluronan has been demonstrated to increase MSC attachment to cartilage [45]. Following joint injury, MSCs must mobilize to injured tissues. Interestingly, anterior cruciate ligament rupture in a rat model induced migration of intravenously injected MSC to the synovium of the injured joint [46]. Although no changes in serum cytokines were observed between rupture and control groups in this study, synovial fluid cytokines were not evaluated.

Given the significance of galectin-1 and - 3 in articular inflammation, we asked how equine BMSC galectin-1 and -3 expression compares to other articular tissuederived cells and whether inflammatory cytokine priming would alter galectin- 1 and galectin- 3 expression in BMSCs. Second, we investigated the role of the inflammatory cytokines IL-1 $\beta$ and TNF- $\alpha$ and the pan-galectin inhibitor $\beta$-lactose on BMSC motility. We hypothesized that equine BMSCs would express high levels of galectin-1 and -3 , and that galectin-1 may account for some beneficial properties of intra-articular BMSC administration. Therefore, the overall objectives of our 
study were to: (1) quantify galectin-1 and -3 gene expression in equine BMSCs, synoviocytes and chondrocytes, and (2) evaluate the effect of inflammatory cytokines on BMSC galectin expression, protein expression, protein secretion and BMSC motility.

\section{Methods}

All animal and tissue harvesting protocols were approved by Cornell University's Institutional Animal Care and Use Committee (Protocol Number: 2011-0027).

\section{Cell isolation and culture}

Bone marrow was collected from the sternebrae of 31 standing, sedated Quarter Horse, Warmblood and Thoroughbred horses $(n=10$ female, 2 intact male and 19 castrated male) ranging in age from 3 to 12 years old for primary BMSC isolation as previously described [47]. Briefly, bone marrow biopsy needles (Jamshidi, VWR Scientific, Bridgeport, NJ, USA) were used to aspirate 60$180 \mathrm{~mL}$ of sternebral bone marrow into one to three $60 \mathrm{~mL}$ syringes containing heparin (APP Pharmaceuticals, LLC, Schaumburg, IL, USA) at a final concentration of 1,000 units $/ \mathrm{mL}$. BMSCs were isolated via selective tissue culture plastic adherence after plating bone marrow 1:1 in Dulbecco's modified Eagles' media; 1,000 mg/L glucose (Gibco-Life Technologies, Grand Island, NY, USA) supplemented with $1 \mathrm{ng} / \mathrm{mL}$ bFGF (Gibco, Invitrogen, Camarillo, CA, USA), 25 mM HEPES (Gibco-Life Technologies, Grand Island, NY, USA), 100 units $/ \mathrm{mL}$ penicillinstreptomycin, and $10 \%$ fetal calf serum. Non-adherent cells were removed via media changes every other day. Following colony formation, adherent cells were passaged and replated at $10-12,000 \mathrm{cells} / \mathrm{cm}^{2}$. Cells were thawed following cryopreservation, cultured for $72 \mathrm{~h}$, collected in lysis buffer and frozen at $80{ }^{\circ} \mathrm{C}$ for subsequent RNA isolation for constitutive galectin gene expression analysis. Bone marrow was collected from the sternebrae of an additional six standing, sedated Thoroughbred-type horses $(\mathrm{n}=2$ female and 4 castrated male) ranging in age from 1 to 8 years old and culture expanded as described above for use in cytokine gene and protein expression, confocal imaging and migration experiments. All cells were stored cryopreserved prior to experiments.

\section{Differentiation assay}

Adipogenic, osteogenic and chondrogenic differentiation potential of primary BMSC lines was evaluated using standard protocols following induction with StemPro ${ }^{\circ}$ differentiation kits (Thermo Fisher Scientific, Waltham, MA, USA). Adipogenic and osteogenic differentiation were induced in confluent monolayer cultures, and chondrogenic differentiation was induced in $5 \mu \mathrm{L}$ cell pellets. Differentiated cells and non-induced controls were stained with Oil Red O, Alizarin Red, or Toluidine
Blue between 7 and 14 days and photographed with $\mathrm{a} \times$ 20, 0.7 NA objective using an Olympus IX73 microscope equipped with an Olympus DP80 CCD camera (Olympus, Tokyo, Japan).

Synovial membrane $(n=27)$ and articular cartilage $(n=$ 16) tissues were aseptically harvested from the shoulder, stifle, carpal and fetlock joints of Thoroughbred, Warmblood and Quarter Horse cadavers $(n=9$ female, 6 intact male and 12 castrated male) ranging in age from 1 to 8 years old immediately post-euthanasia. All horses were healthy without gross signs of OA at dissection. Cells were isolated, pooled and culture expanded as previously described for synoviocytes [48] and chondrocytes [49]. Briefly, synovial lining was digested in $0.15 \%$ collagenase (Worthington Biochemical, Lakewood, NJ, USA) and 0.015\% DNAseI (Roche, Indianapolis, IN, USA) for $3 \mathrm{~h}$ at $37{ }^{\circ} \mathrm{C}$, followed by filtration and centrifugation at $250 \times g$ for 10 minutes. Synoviocytes were cultured in Dulbecco's modified Eagles' media; 4500 mg/L glucose (Gibco-Life Technologies, Grand Island, NY, USA) supplemented with 25 mM HEPES, 100 units $/ \mathrm{mL}$ penicillin-streptomycin, and $10 \%$ fetal calf serum. Articular cartilage was digested in $0.075 \%$ collagenase overnight at $37{ }^{\circ} \mathrm{C}$, followed by filtration and centrifugation at $250 \times g$ for 10 minutes. Chondrocytes were cultured in Ham's F12 medium (Corning Inc., Corning, NY, USA) supplemented with $50 \mu \mathrm{g} / \mathrm{mL}$ ascorbic acid, $30 \mu \mathrm{g} / \mathrm{mL} \alpha$ ketoglutarate, $300 \mu \mathrm{g} / \mathrm{mL}$ L-glutamine, $25 \mathrm{mM}$ HEPES, 100 units $/ \mathrm{mL}$ penicillin-streptomycin and $10 \%$ fetal calf serum.

\section{Equine galectin gene expression analysis}

For constitutive galectin expression, passage 1 to 3 equine BMSCs $(n=31)$, synovial fibroblasts $(n=27)$ and chondrocytes $(n=16)$ were cultured for $72 \mathrm{~h}$ after thawing in appropriate growth media as discussed above. Cells were collected in lysis buffer and frozen at $\quad 80{ }^{\circ} \mathrm{C}$ for subsequent RNA isolation using a purification kit (5 Prime Inc., Gaithersburg, MD, USA). Synovial membrane and cartilage tissue obtained from healthy equine carpal joints at the time of surgery or euthanasia $(n=23)$ from a previous study [50] that had been stored at $80{ }^{\circ} \mathrm{C}$ was thawed for RNA isolation and purification using the same purification kit. RNA purity and concentration were assessed using UV microspectrophotometry (NanoDrop 2000, Thermo Fisher Scientific, Waltham, MA, USA). Gene expression was quantified through the use of quantitative real-time polymerase chain reaction (qRT-PCR) using the ABI PRISM 7900 sequence detection system (Applied Biosystems, Foster City, CA, USA), with all samples analyzed in duplicate using primers and a dual-labeled fluorescent probe $\left(6-\mathrm{FAM}^{\mathrm{sm}}\right.$ as the $5^{\prime}$ reporter label and Iowa Black $^{\circ} \mathrm{FQ}$ as the $3^{\prime}$ quenching label). Primers and probes were generated using the equine galectin-1 
and -3 sequences as described above and were designed using Primer Express software (Primer Express v2.0b8, Foster City, CA, USA):

(Galectin-1 Fwd: 5'- CAAGGCAGACCTGACCATCA - 3, Galectin-1 Rev: 5'- TCACGGCCTCCAGGTTGA -3', Galectin-1 Probe: 5'-/56-FAM/CTGCCGGAT/ZEN/ GGCTACTCGTTCAAGTTC/3IABkFQ/-3', Galectin-3 Fwd: 5'-

TAAATTTCAACAGAGGGCATGATG -3', Galectin-3 Rev: 5'CAATGACTCTCCTGTTGTTCTCGTT -3' Galectin-3 Probe: 5'-/56-FAM/TGCCTTCCA/ZEN/ CTTTAACCCGCGCTT/3IABkFQ/-3').

Total copy number of mRNA was determined from a validated standard curve using serial dilutions of $E$. coliexpressed equine galectin- 1 and -3 as standards for absolute quantitation, and copy number was normalized to the housekeeping gene $18 \mathrm{~S}$.

\section{Cytokine treatments}

For inflammatory cytokine treatments, passage 3 BMSCs $(n=3)$ were plated in duplicate in 24-well plates at a concentration of $2 \times 10^{4}$ cells $/ \mathrm{cm}^{2}$. BMSCs remained in serum-containing MSC growth media for $24 \mathrm{~h}$ prior to cytokine treatments. Serum-containing media was replaced with serum-free Opti-MEM (Invitrogen, Grand Island, NY, USA) $4 \mathrm{~h}$ prior to stimulation. BMSCs were stimulated with recombinant equine IL-1 $\beta$ (IBI Scientific, Peosta, IA, USA) at $5 \mathrm{ng} / \mathrm{mL}$ and $10 \mathrm{ng} / \mathrm{mL}$, recombinant equine TNF- $\alpha$ (IBI Scientific, Peosta, IA, USA) at $25 \mathrm{ng} / \mathrm{ml}$ and $50 \mathrm{ng} / \mathrm{ml}$ or LPS from E. coli 055:B5 (Sigma-Aldrich, St. Louis, MO, USA) at $0.1 \mu \mathrm{g} / \mathrm{mL}, 1 \mu \mathrm{g} / \mathrm{mL}, 10 \mu \mathrm{g} / \mathrm{mL}$ and $50 \mu \mathrm{g} / \mathrm{mL}$. BMSCs remained in serum-free Opti-MEM as the control condition. Media supernatants were collected at 4, 8, 20 and $30 \mathrm{~h}$ post-treatment, frozen and stored at $80{ }^{\circ} \mathrm{C}$ for galectin quantification via custom ELISA. Cells were lysed at 4, 8, 20 and $30 \mathrm{~h}$ after treatment for RNA isolation, and gene expression was determined using qRT-PCR for galectin-1 and galectin-3 mRNA with $18 \mathrm{~S}$ used as a housekeeping gene. In parallel, BMSCs were lysed at 4, 8, 20 and $30 \mathrm{~h}$ after treatment with ice-cold RIPA buffer containing protease inhibitors. Cell lysates were stored at $-80{ }^{\circ} \mathrm{C}$ for immunoblotting analysis.

\section{Equine galectin protein expression after cytokine stimulation}

Custom ELISAs were developed for the detection of equine galectin-1 and galectin-3 in BMSC media supernatants following cytokine stimulation. Equine galectin-1 (GenBank ID: KY264050) and galectin-3 (GenBank ID: KY264051) were cloned and sequenced from renal tissue obtained from a 19-year-old Thoroughbred cadaver mare as previously reported [33]. In order to assess antibody cross-reactivity and to establish equine-specific standards for galectin ELISAs, equine galectins- 1 and -3 were recombinantly expressed and purified as described for human galectins-1, -3 and $-3 \mathrm{C}$ [51]. All antibodies were validated to react against purified equine galectin-1 or galectin-3 using dot blots (Additional file 1). Briefly, for the custom competitive equine galectin-1 ELISA, 96well high-binding plates (Corning Inc., Corning, NY, USA) were coated with $1 \mathrm{ug} / \mathrm{mL}$ of capture antibody (R\&D Systems, Minneapolis, MN, USA; goat anti-mouse Gal-1 pAb, AF1245) in sodium carbonate buffer, pH 9.6 overnight at $4{ }^{\circ} \mathrm{C}$. After rinsing $3 \times$ in $0.1 \%$ PBS-Tween, protein-free blocking buffer (Thermo Fisher Scientific, Rockford, IL, USA) was added for $1 \mathrm{~h}$. Unlabeled recombinant equine galectin-1 standards (4000 to $15.63 \mathrm{ng} / \mathrm{mL}$, plus $0 \mathrm{ng} / \mathrm{mL}$ ) were diluted in a solution of $200 \mathrm{ng} / \mathrm{mL}$ biotinylated recombinant equine galectin-1 in $0.1 \%$ PBSTween. Supernatants from passage 3 BMSCs $(n=3)$ were collected in duplicate for all treatment conditions (control, IL-1 $\beta 5$ and $10 \mathrm{ng} / \mathrm{mL}$, TNF- $\alpha 25$ and $50 \mathrm{ng} / \mathrm{ml}$, and LPS $0.1 \mu \mathrm{g} / \mathrm{mL}, 1 \mu \mathrm{g} / \mathrm{mL}, 10 \mu \mathrm{g} / \mathrm{mL}$ and $50 \mu \mathrm{g} / \mathrm{mL}$ ) at all time points $(4,8,20$ and $30 \mathrm{~h})$. Supernatants were diluted 1:10 in $200 \mathrm{ng} / \mathrm{mL}$ biotinylated recombinant equine galectin-1 in $0.1 \%$ PBS-Tween. Blocking buffer was removed, and $100 \mu \mathrm{L}$ of recombinant equine galectin-1 standards or samples were added to wells, covered, and incubated for $1 \mathrm{~h}$ at RT on a plate shaker. After rinsing $3 \times$ in $0.1 \%$ PBSTween, $100 \mu \mathrm{L}$ of streptavidin HRP was added for 30 minutes, followed by $5 \times$ rinses in $0.1 \%$ PBS-Tween. TMB reagent (Thermo Fisher Scientific, Rockford, IL, USA) was added for 30 minutes, and the reaction was stopped with $1 \mathrm{~N} \mathrm{H}_{2} \mathrm{SO}_{4}$. Absorbance was measured at $450 \mathrm{~nm}$ with $540 \mathrm{~nm}$ background subtraction, and all measurements were performed in duplicate.

For the equine galectin-3 sandwich ELISA, 96-well high-binding plates were coated with $2 \mathrm{ug} / \mathrm{mL}$ of capture antibody (Santa Cruz Biotechnology, Dallas, TX, USA; goat anti-human Gal-3 pAb, sc-19280) in sodium carbonate buffer, $\mathrm{pH} 9.6$ overnight at $4{ }^{\circ} \mathrm{C}$. After rinsing $3 \times$ in $0.1 \%$ PBS-Tween, protein-free blocking buffer was added for $1 \mathrm{~h}$. Blocking buffer was removed, and serial dilutions of recombinant equine galectin- 3 standards (400 $\mathrm{ng} / \mathrm{mL}$ to1.56 $\mathrm{ng} / \mathrm{mL}$, plus $0 \mathrm{ng} / \mathrm{mL}$ ) or $1: 1$ dilutions of BMSC supernatants in PBS $+2 \%$ BSA were incubated for $1 \mathrm{~h}$. After rinsing $3 \times$ in $0.1 \%$ PBS-Tween, biotinylated detection antibody (R\&D Systems Minneapolis, MN, USA; biotinylated goat anti-mouse Gal-3 pAb, BAF1197) was added at $200 \mathrm{ng} / \mathrm{mL}$ for $1 \mathrm{~h}$. Plates were rinsed, and $100 \mu \mathrm{L}$ of streptavidin HRP was added for 30 minutes, prior to $3 \times$ rinses in $0.1 \%$ PBS-Tween and addition of TMB reagent for 30 minutes. The TMB reaction was stopped with $1 \mathrm{~N} \mathrm{H}_{2} \mathrm{SO}_{4}$, and absorbance was 
measured at $450 \mathrm{~nm}$ with $540 \mathrm{~nm}$ background subtraction. All measurements were performed in duplicate.

In order to measure intracellular and membranebound galectins after cytokine stimulation, cell lysates were thawed and heated at $95{ }^{\circ} \mathrm{C}$ in reducing SDS-PAGE loading buffer for 15 minutes. $10 \mu \mathrm{L}$ of sample per well was loaded onto a 7.5\% TGX gel (Bio-Rad, Hercules, CA, USA), and subjected to SDS-PAGE for $1 \mathrm{~h}$ at $100 \mathrm{~V}$. Gels were transferred to PVDF membranes (EMD Millipore, Billerica, MA, USA), and immunoblotting was performed using antibodies against galectin-1 (R\&D Systems, Minneapolis, MN, USA) goat anti-mouse Gal-1 pAb, AF1245), galectin-3 (Santa Cruz Biotechnology, Dallas, TX, USA; goat anti-human Gal-3 pAb, sc-19280) and actin (Santa Cruz Biotechnology, Dallas, TX, USA; goat anti-human actin pAb, sc-1615). Band intensities were quantified using $\mathrm{NIH}$ Fiji, with background subtraction, and galectin-1 and -3 band intensities were normalized to actin. Only monomeric galectins (approximately $17 \mathrm{kDa}$ for galectin-1 and approximately $31 \mathrm{kDa}$ for galectin-3) were quantified.

\section{BMSC nucleofection and confocal imaging}

Passage 3 to 4 equine BMSCs $(n=3)$ were nucleofected with the fluorescent-protein tagged adhesion markers paxillin mEmerald and vinculin mApple using a human MSC nucleofector kit (Lonza, Basel, Switzerland). Cells were passaged at $48 \mathrm{~h}$ post-nucleofection and plated onto 12-well fibronectin-coated glass plates at a concentration of $2 \times 10^{3}$ cells $/ \mathrm{cm}^{2}$ in serum-free media (Dulbecco's modified Eagles' media, $1000 \mathrm{mg} / \mathrm{L}$ glucose; $1 \mathrm{ng} / \mathrm{mL}$ bFGF; 25 mM HEPES; 100 units $/ \mathrm{mL}$ penicillinstreptomycin). BMSCs were plated in the presence and absence of $100 \mathrm{mM} \beta$-lactose (Santa Cruz Biotechnology Inc., Dallas, TX, USA). At $8 \mathrm{~h}$ post-plating, glass plates were fixed in $4 \%$ paraformaldehyde for 10 minutes, rinsed in PBS, followed by actin staining with phalloidin Alexa647 and nuclear staining with DAPI for 15 minutes, followed by several PBS rinses. Cells were imaged with a $\times 100$, NA 1.3 objective on an Olympus IX83 microscope equipped with a Yokagawa X1 spinning disk confocal scanning unit and an Andor Ultra 897 EMCCD camera. Images were overlaid in Adobe Photoshop CS5 (Adobe Systems Inc., San Jose, CA, USA).

\section{Equine BMSC migration assays}

Passage 3 to 4 equine BMSCs $(n=3)$ were plated onto 24-well tissue culture plates (Corning Inc., Corning, NY, USA) within silicone inserts containing a defined, $500 \mu \mathrm{m}$ cell-free gap (Ibidi ${ }^{\bullet}$, Martinsried, Germany) for migration assays. After $6 \mathrm{~h}$, media was changed to either control media, media containing $\beta$-lactose $(100 \mathrm{mM}$, $200 \mathrm{mM}$ ) or media supplemented with recombinant equine IL-1 $\beta$ ( $5 \mathrm{ng} / \mathrm{mL}, 10 \mathrm{ng} / \mathrm{mL})$ or recombinant equine TNF- $\alpha$ ( $25 \mathrm{ng} / \mathrm{ml} 50 \mathrm{ng} / \mathrm{ml})$. Twenty hours later, inserts were removed and media was replaced with control media or media containing $\beta$-lactose $(100 \mathrm{mM}$, $200 \mathrm{mM})$. Phase contrast images were obtained at 0,3 , $8,12,24$ and 48 hours following insert removal, using three images/well obtained with a $\times 10$, NA 0.25 objective on an Olympus CK2 microscope with a Nikon Digital Sight DS-Fil CCD camera to image the entire cell-free gap. NIH Fiji was used to define the $\mathrm{x}, \mathrm{y}$ coordinates of the leading edges of cells migrating across the cell-free region. Custom software (Python Software Foundation, Wilmington, DE, USA) was designed to measure the mean linear cell-free distance for each image, which was normalized to the cell-free distance at time zero for each treatment.

\section{Statistical analysis}

For constitutive galectin gene expression, a one-way ANOVA with Tukey's post hoc tests was performed on log-transformed gene expression data for galectin-1 and galectin-3 using statistical software (GraphPad Software Inc., La Jolla, CA, USA). Summary statistics were performed on the untransformed data, and significance was set at $p<0.05$. Galectin- 1 and galectin-3 gene expression after stimulation data were compared using a Friedman nonparametric test, matching data by primary cell line (GraphPad Software Inc., La Jolla, CA, USA). Post hoc comparisons between all treatment groups and the control group were made using the method described by Gibbons and Chakraborti (p. 459, equation 2.13) [52] with a Bonferroni correction for multiple comparisons and significance set at $p<0.05$.

Galectin-1 and galectin-3 immunoblotting and ELISA protein expression after stimulation data were also compared using a Friedman nonparametric test, matching data by primary cell line (GraphPad Software Inc., La Jolla, CA, USA). Post hoc comparisons between all treatment groups and the control group were made using the method described by Gibbons and Chakraborti (p. 459, equation 2.13) [52] with a Bonferroni correction for multiple comparisons and significance set at $p<0.05$. Migration experiments were performed using three BMSC primary cell lines, and all treatment conditions were applied in duplicate. The normalized mean cellfree distances were analyzed using statistical software (JMP 11.0, Cary, NC, USA) to perform linear regression model fitting. Parameters included treatment, time, and BMSC primary cell line. Tukey's honest significant difference (HSD) post hoc tests were performed to compare the effects of time and BMSC primary cell line, with significance set at $p<0.05$. Dunnett's post hoc tests were performed to compare the effects of each treatment condition to the control condition, with significance set at $p<0.05$. 


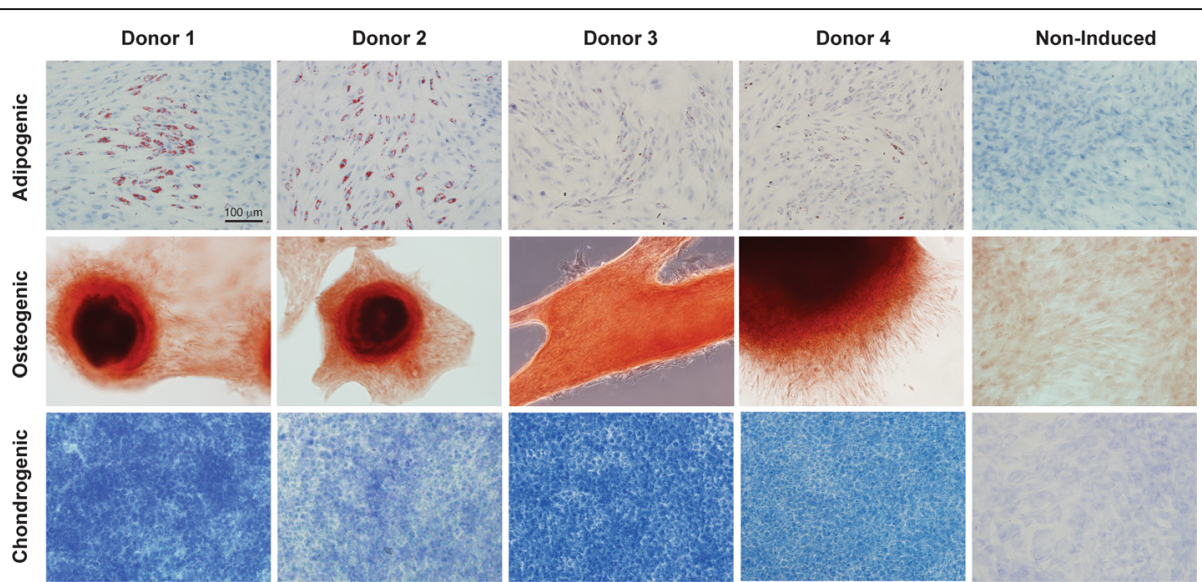

Fig. 1 Tri-lineage differentiation of equine BMSCs. Representative microscopic images of Oil Red O, Alizarin Red, and Toluidine Blue staining to confirm adipogenic, osteogenic and chondrogenic differentiation of plastic adherent bone-marrow derived cell populations from four adult equine primary BMSC donors 7-14 days post-induction. Representative non-induced images from donor 1 are included for comparison. All images are obtained with a $\times 20,0.7$ NA objective

\section{Results}

\section{Differentiation assay}

Tri-lineage differentiation capability was demonstrated in all primary BMSC lines used for cytokine stimulation experiments, confocal imaging experiments, and migration experiments (Fig. 1).

\section{BMSC galectin expression}

BMSCs expressed approximately 3-fold higher galectin-1 as compared to cultured synoviocytes $(p=0.001)$ and 30 -fold higher galectin-1 $(p<0.0001)$ relative to cultured articular chondrocytes (Fig. 2). Galectin-1 mRNA expression was 8-fold higher in BMSCs as compared to freshly isolated synovial membrane tissue $(p<0.0001)$ and more than 600-fold higher in BMSCs than articular cartilage $(p<0.0001)$. BMSC galectin-3 expression was not significantly different from cultured synoviocytes, cultured chondrocytes or freshly harvested synovial membrane and cartilage tissues. Galectin- 1 and -3 expression did not vary significantly with passage from passage 1 to passage 3 BMSCs (data not shown). Galectin1 expression was elevated in cultured articular cells as compared to freshly harvested joint tissues, with galectin1 significantly increased in cultured synoviocytes as compared to synovial membrane tissue $(p=0.004)$ and cultured chondrocytes as compared to articular cartilage tissue $(p<0.0001)$.

\section{Cytokine-influenced BMSC galectin gene and protein expression}

The pro-inflammatory cytokines IL- $1 \beta$ and TNF- $\alpha$ decreased both galectin- 1 and galectin-3 mRNA expression in equine BMSCs. IL- $1 \beta$ at $5-10 \mathrm{ng} / \mathrm{mL}$ decreased BMSC galectin-1 and galectin-3 mRNA expression more than 3 -fold at $20 \mathrm{~h}$ post-exposure (Fig. 3a, b). Exposure to $25-50 \mathrm{ng} / \mathrm{mL}$ of TNF- $\alpha$ also decreased galectin- 1 and galectin-3 mRNA expression, but to a lesser extent than IL-1 $\beta$ (Fig. 3a, b). The effect of LPS treatment was less pronounced. LPS did not significantly decrease galectin1 mRNA expression at $20 \mathrm{~h}$ (Fig. 3a), and only the

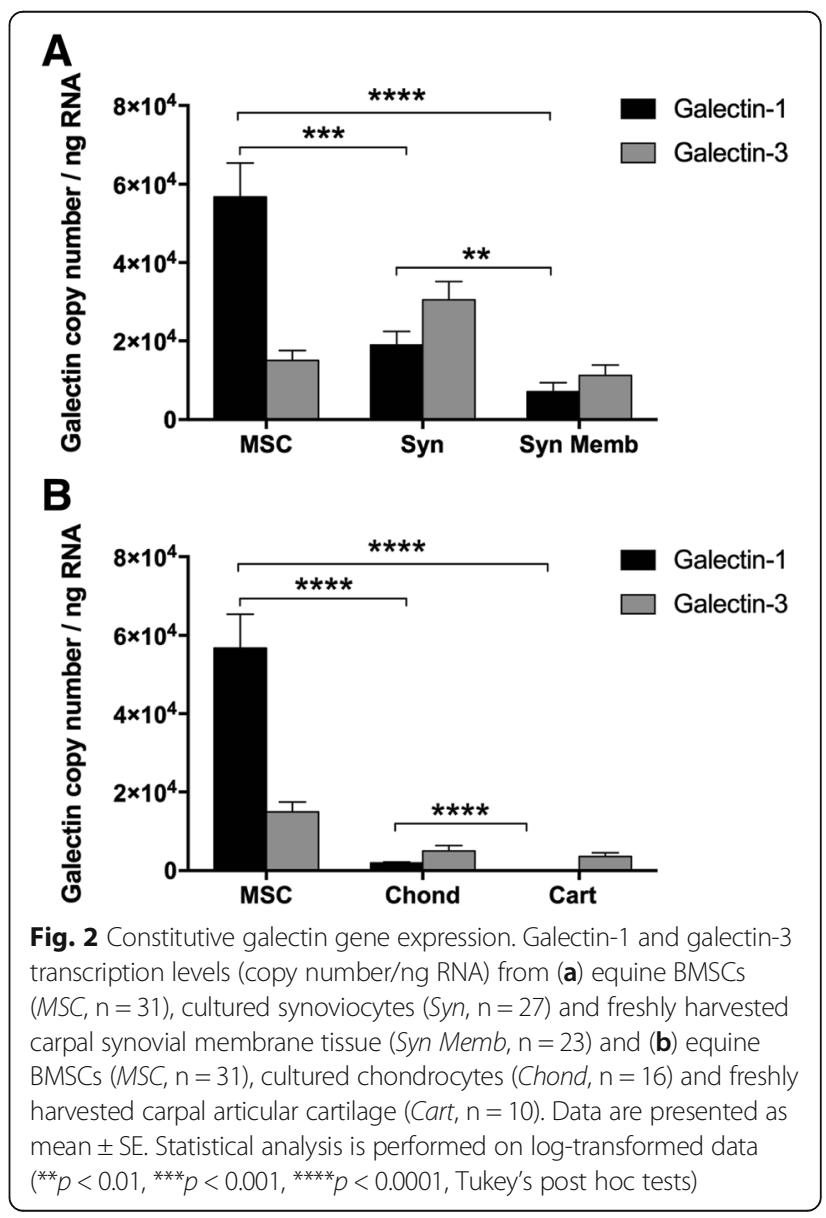




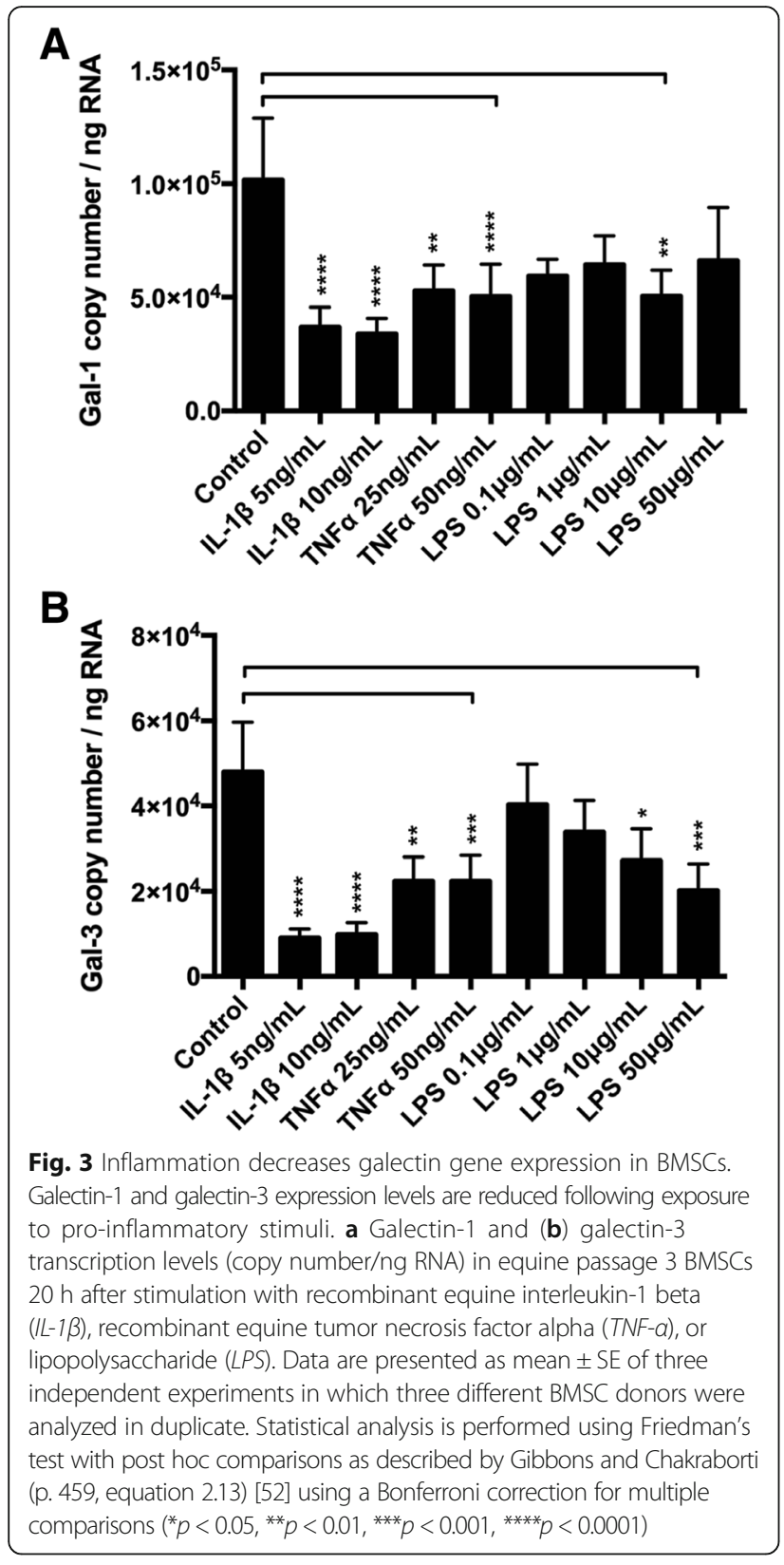

highest LPS dose of $50 \mu \mathrm{g} / \mathrm{mL}$ resulted in a decrease in galectin-3 mRNA expression ( $p=0.05$, Fig. $3 \mathrm{~b}$ ).

Although galectin mRNA expression decreased following exposure to both IL- $1 \beta$ and TNF- $\alpha$, no changes were observed in galectin protein concentrations in media supernatants upon treatment with either cytokine at $20 \mathrm{~h}$ post-exposure (Fig. 4). Immunoblotting of BMSC lysates similarly did not reveal any quantitative differences in intracellular or membrane-bound galectins-1 and 3 (Fig. 4). LPS treatment at $50 \mu \mathrm{g} / \mathrm{mL}$ resulted in an increase in galectin-1 protein concentrations in media supernatants $20 \mathrm{~h}$ post-exposure, whereas galectin-3 concentrations in media supernatants did not significantly differ from controls (Fig. 4).

\section{BMSC adhesion with focal adhesion markers}

When plated on fibronectin-coated glass substrates, equine passage 4 BMSCs nucleofected with paxillin demonstrated distinct focal adhesions at the cell periphery (Fig. 5). In addition, focal adhesions were associated with actin stress fibers, indicating mature, mechanically stable adhesive structures. The addition of $100 \mathrm{mM} \beta$ lactose inhibited adhesion complex assembly, suggesting that galectins play a role in BMSC adhesion, at least in part through integrin-mediated mechanisms.

\section{BMSC cell migration}

Regression analysis of migration data revealed a dosedependent reduction in BMSC motility in the presence of $\beta$-lactose (Fig. 6a, Additional file 2). IL-1 $\beta$ (5 ng/mL, $10 \mathrm{ng} / \mathrm{mL})$ and TNF- $\alpha(25 \mathrm{ng} / \mathrm{mL}, 50 \mathrm{ng} / \mathrm{mL})$ both significantly decreased BMSC motility relative to untreated controls (Fig. 6b, Additional file 2).

\section{Discussion}

Equine BMSCs constitutively express elevated levels of galectin-1 relative to other articular cell types. Galectin1 and galectin- 3 have both been previously identified in the proteome of fibroblast-like synoviocytes from patients with rheumatoid arthritis [53]. Although galectin gene expression has not been extensively studied in articular cartilage, galectin-3 gene expression was increased more than 2-fold in human OA cartilage as compared to normal cartilage [34]. In order to determine how galectin expression in equine BMSCs compared to galectin expression in other articular tissues, galectin- 1 and -3 mRNA was quantified in synovial membrane and articular cartilage tissues obtained from the carpal joints of horses without evidence of OA. Furthermore, in order to evaluate the effect of tissue culture expansion, galectin expression was measured in freshly harvested articular tissues, in addition to cultured synoviocytes and chondrocytes. Although culturing cells increased galectin-1 expression in both synoviocytes and chondrocytes, galectin-3 mRNA expression was unchanged. BMSC galectin-1 expression remained significantly higher than either cultured synoviocytes or chondrocytes.

Galectin-1 and -3 expression was lowest in healthy equine articular cartilage tissue and cultured chondrocytes. Galectins-1, -3 and -8 have been documented at both gene and protein levels in cultured human OA chondrocytes, and immunohistochemical staining has revealed elevation of galectin-1 in areas of severe cartilage degeneration [35] and elevation of galectin-3 in OA chondrons [54]. Altered glycosylation in human OA 

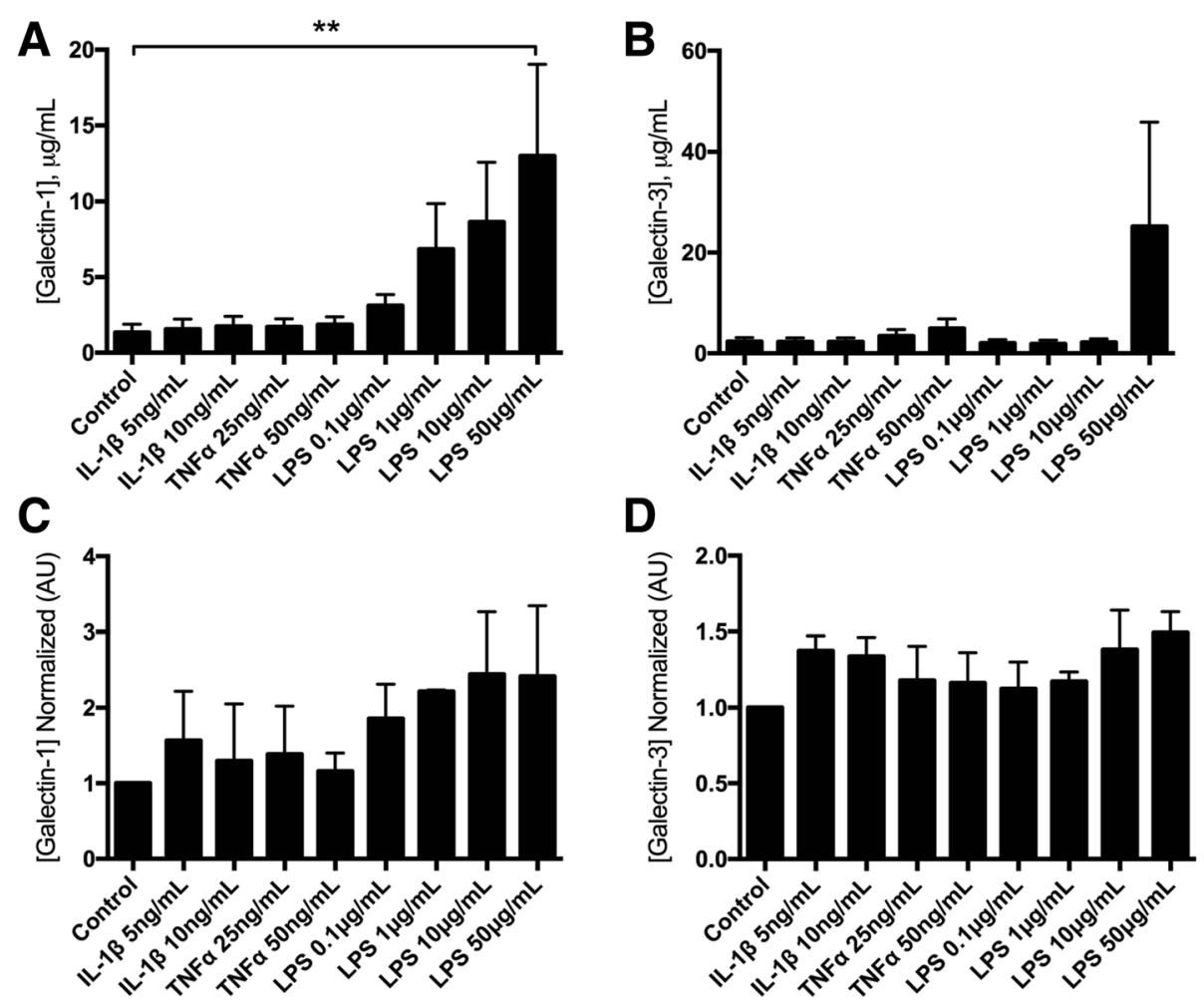

Fig. 4 Secreted and intracellular/membrane-bound galectins in BMSCs. a Galectin-1 and (b) galectin-3 secretion ( $\mu \mathrm{g} / \mathrm{mL})$ measured in the supernatants of cytokine- or LPS-treated equine passage 3 BMSCs $20 \mathrm{~h}$ following treatment. c Galectin-1 and (d) galectin-3 concentrations measured in cell lysates from cytokine- or lipopolysaccharide (LPS)-treated equine passage 3 BMSCs $20 \mathrm{~h}$ following treatment. For all graphs, data are presented as mean \pm SE of three independent experiments in which three different BMSC donors were analyzed in duplicate. Statistical analysis is performed using Friedman's test with post hoc comparisons as described by Gibbons and Chakraborti (p. 459, equation 2.13) [52] using a Bonferroni correction for multiple comparisons. Galectin-1 concentrations were increased only in supernatants from MSCs exposed to the $50 \mu \mathrm{g} / \mathrm{mL}$ dose of LPS (** $p<0.01$ ). No significant differences were observed for galectin-3 supernatants or galectin-1/galectin-3 cell lysates. IL-1 $\beta$ interleukin-1 beta; TNF- $a$ tumor necrosis factor alpha

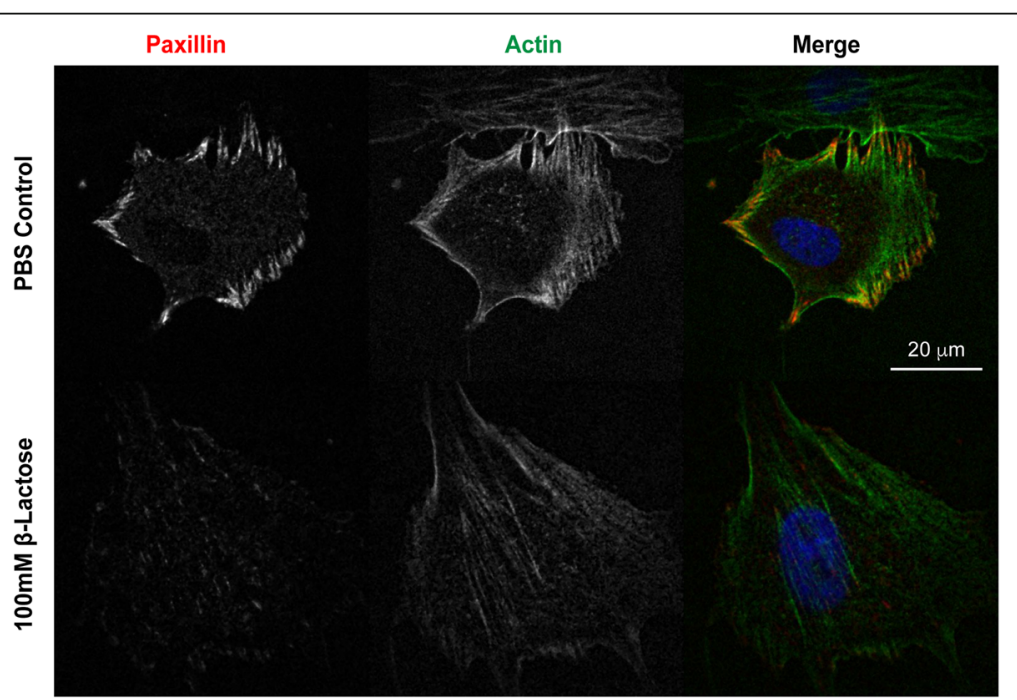

Fig. 5 Galectins promote focal adhesion formation. Equine passage 4 BMSCs plated on fibronectin-coated glass substrates following nucleofection with the focal adhesion marker paxillin mEmerald and staining for actin (phalloidin Alexa647) and nuclei (DAPI). Distinct focal adhesion structures are present within BMSCs plated in control media but not in media with $100 \mathrm{mM} \beta$-lactose 


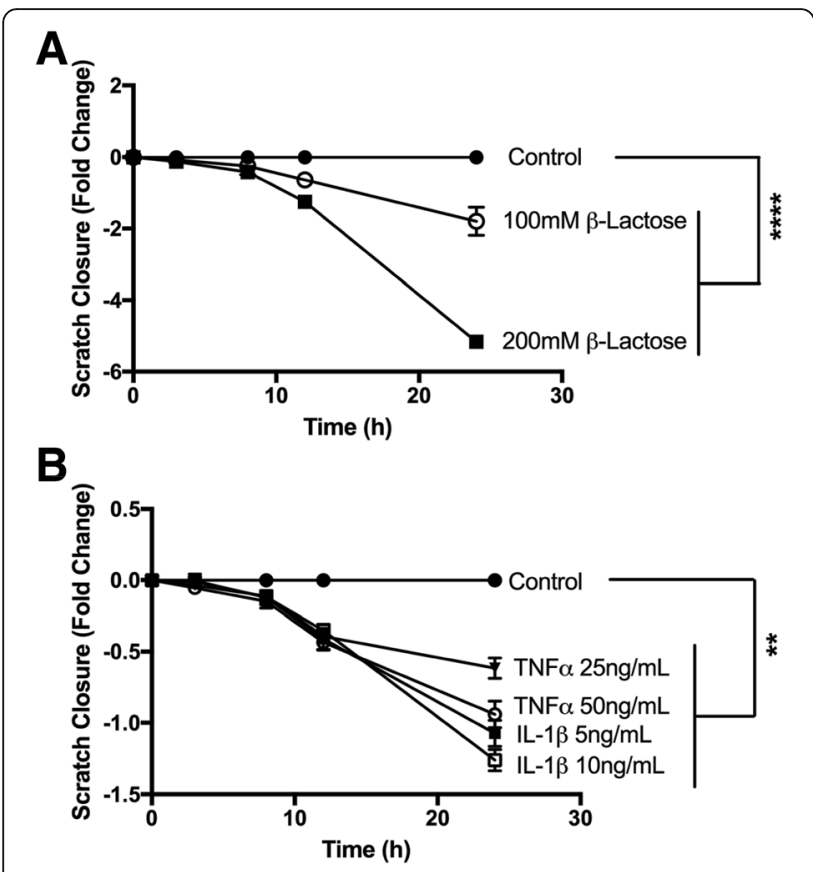

Fig. 6 BMSC migration data. Scratch closure by equine passage 3 BMSCs, expressed as fold change in a $500 \mu \mathrm{m}$ cell-free gap as compared to the control treatment for each time point. Data are presented as mean \pm SE from three independent experiments performed in duplicate. a Treatment with $100 \mathrm{mM} \beta$-lactose and $200 \mathrm{mM} \beta$-lactose significantly abrogated BMSC motility as compared to control $(p<0.0001$, Dunnett's test). $\mathbf{b}$ Treatment with the pro-inflammatory cytokines interleukin-1 beta $(I L-1 \beta)$ or tumor necrosis factor alpha (TNF- $a$ ) decreased BMSC motility as compared to control ( $p<0.01$, Dunnett's test)

chondrocytes induced by IL- $1 \beta$ and TNF- $\alpha$ has led authors to speculate that galectin function may be altered under inflammatory arthritis conditions [55]. Access to healthy human articular cartilage is limited by tissue availability; therefore, findings in human tissues may be skewed toward a disease or OA phenotype. Furthermore, changes in galectin gene and protein expression in human articular cartilage are not necessarily paralleled by synovial membrane or synovial fluid changes.

For example, although human articular chondrocytes appear to increase galectin expression under inflammatory OA conditions, synovial fluid galectin-1 concentrations are decreased in human OA [29], juvenile idiopathic arthritis [30, 31] and rheumatoid arthritis [32]. Furthermore, elevated synovial fluid galectin-1 concentrations have been shown to protect against the development OA. Evidence supporting the protective role of galectin-1 in OA can be extrapolated from murine models where galectin-1 gene therapy and recombinant galectin-1 intra-articular administration ameliorated adjuvant-induced arthritis [38, 56]. Gal1/-1 knockout mice show exacerbation of post-traumatic arthritis [37]. The mechanistic roles of galectin-1 and galectin-3 in human and equine arthritis are less well understood; however, increased synovial fluid galectin-1 is thought to be protective as galectin-1 is immunomodulatory in other chronic inflammatory diseases [27, 28].

We observed constitutive galectin-1 and -3 mRNA expression in equine synovial fibroblast cultures; however, equine BMSCs expressed significantly higher levels of galectin-1 and increased galectin-1:galectin-3 ratios as compared to other articular-derived cells. BMSCs had an elevated galectin-1:galectin-3 ratio (3.77) as compared to synoviocytes and chondrocytes $(0.62$ and 0.34 , respectively) and synovial membrane and articular cartilage tissue (0.65 and 0.02, respectively). Elevated expression of galectin-1 relative to galectin-3 may contribute to the beneficial immunomodulatory properties of BMSCs based on prior studies suggesting that increased galectin-1 and decreased galectin-3 synovial fluid concentrations are anti-inflammatory and ameliorate the progression of OA [31, 37, 38, 57]. Furthermore, galectin-1 has been shown to confer immunomodulatory properties of MSCs through inhibition of $\mathrm{T}$ cells $[15,17,21]$ and attenuation of proinflammatory cytokine expression [58].

In the presence of the inflammatory cytokines IL-1 $\beta$ and TNF- $\alpha$, equine BMSCs downregulated expression of both galectin-1 and galectin-3 mRNA. Although downregulation of galectin-1 might be detrimental to the immunomodulatory properties of intra-articularly injected BMSCs, decreases in galectin gene expression were not paralleled by decreases in protein expression in BMSC lysates or media supernatants. One possibility for the discrepancy between the gene and protein expression results is that galectin mRNA levels do not predict protein levels due to variation in rates of translation, protein stability, and/or protein degradation. Several studies have demonstrated that a gene's mRNA level is not necessarily a good predictor of protein level, with correlation coefficients between gene and protein expression rarely exceeding $0.43[59,60]$. Another possibility is that $20-30 \mathrm{~h}$ was not a sufficient period of time to observe protein-level changes in cultured BMSCs. A previous report revealed that TNF- $\alpha$ reduced galectin-3 protein expression as measured by flow cytometry in human $\mathrm{OA}$ and rheumatoid arthritis synovial fibroblasts 18 hours following exposure to TNF- $\alpha$ [61]. To our knowledge, MSC galectin-1 and -3 protein expression has not been previously quantified by ELISA or immunoblotting in response to IL- $1 \beta$ and TNF- $\alpha$. Future studies may need to evaluate MSC galectin protein expression at longer intervals following inflammatory cytokine exposure to confirm that galectin protein expression is not changing significantly. In addition, although the concentrations of pro-inflammatory cytokines tested were similar to those used in prior studies $[43,62]$, it is likely that the concentrations used in this study are much higher than those found in naturally occurring equine $\mathrm{OA}[50]$. 
Confocal imaging of equine BMSCs nucleofected with the focal adhesion protein paxillin-mEmerald revealed distinct adhesion complexes on fibronectin-coated glass substrates. Galectins have been shown to interact with integrins [63-66], and integrins play a significant role in MSC adhesion, spreading and motility [67, 68]. Several adhesion-related molecules have been detected in human MSCs, including integrin subunits $\alpha 4, \alpha 5, \beta 1$, $\alpha v \beta 3, \alpha v \beta 5$, ICAM-1 and CD44H [69]. Galectins bind directly to integrins, promoting both integrin clustering [65] and signaling activity [66]. Integrins are thought to play a major role in galectin-3-mediated regulation of cell adhesion [63]. Galectin-3 can bind to integrins such as $\alpha_{1} \beta_{1}$ [70], and galectins can enhance the mechanical strength of adhesive bonds between integrins and extracellular matrix proteins, such as collagen-I and -IV [64]. Interestingly, inhibition of BMSC galectin binding with $100 \mathrm{mM} \beta$-lactose nearly abolished focal adhesion structures and decreased MSC adhesion and spreading. This suggests that galectins play an important role in equine BMSC adhesion to extracellular matrices.

Equine BMSC motility was markedly downregulated in the presence of the pan-galectin inhibitor $\beta$-lactose, suggesting that galectins may play a critical role in stem cell migration. Galectin-3 promotes wound reepithelialization in corneal, intestinal and skin wounds [71], and galectin-1 accelerates skin wound healing [72]. Galectin-1 enhances migration of human monocytederived dendritic cells through extracellular matrices [73] and stimulates motility of human umbilical cord blood-derived MSCs via downregulation of Smad2/3 and upregulation of NF-kB [19]. Conversely, priming of BMSCs with pro-inflammatory cytokines (IL-1 $\beta$ and TNF- $\alpha$ ) decreased BMSC motility. These results are consistent with a prior study in which equine BMSCs exposed to TNF- $\alpha$ and IFN- $\Upsilon$ significantly downregulated migration-related genes such as the chemokine receptor CXCR4 [43]. Further studies would be needed to determine the effects of pro-inflammatory cytokine priming on BMSC motility in vivo and in response to physiologic concentrations of inflammatory cytokines present in OA synovial fluid.

\section{Conclusions}

Equine BMSCs express high levels of galectin-1 mRNA relative to other articular cell types; however, BMSC galectin mRNA expression is diminished in the presence of pro-inflammatory cytokines prevalent in osteoarthritis (IL-1 $\beta$ and TNF- $\alpha$ ). Under the conditions tested in this study, decreased galectin mRNA expression was not paralleled by decreases in galectin protein expression. Therefore, intra-articular administration of BMSCs may be a viable method to achieve therapeutic levels of intraarticular galectin-1, even in the presence of joint inflammation. Pro-inflammatory cytokines and $\beta$-lactose, a pan-galectin inhibitor, impaired BMSC motility. Further investigation into the effects of joint inflammation on BMSC function and the potential therapeutic effects of BMSC galectin expression on joint inflammation and osteoarthritis is warranted.

\section{Additional files}

\begin{abstract}
Additional file 1: Antibody dot blots for recombinant equine galectins. Recombinant equine galectins- 1 and -3 probed with antibodies used for custom galectin ELISAs, including: (A) (R\&D Systems, Minneapolis, MN, USA) goat a-mouse Gal-1 pAb, AF1245, (B) (Santa Cruz Biotechnology, Dallas, TX, USA) goat a-human Gal-3 pAb, sc-19280, and (C) (R\&D Systems, Minneapolis, MN, USA) biotinylated goat a-mouse Gal-3 pAb, BAF1197. Five $\mu \mathrm{L}$ of recombinant equine (reGal) or human (rhGal) galectin or BSA was pipetted onto a nitrocellulose membrane at concentrations of $500 \mu \mathrm{g} / \mathrm{mL}$ (1), $100 \mu \mathrm{g} / \mathrm{mL}$ (1:5) and $20 \mu \mathrm{g} / \mathrm{mL}$ (1:25, top to bottom). Following blocking in milk $+2 \%$ BSA, proteins were immunodetected. (TIF $1538 \mathrm{~kb}$ )

Additional file 2: Regression analysis and least squares means for BMSC migration data. Results of BMSC migration data reported as mean cell-free gap within a $500 \mu \mathrm{m}$ scratch (normalized to time $0 \mathrm{~h}$ ), presented as least squares geometric means and standard error (SE). Effects included time, treatment and equine BMSC primary cell line. The intercept is excluded for clarity. (PDF 34 kb)
\end{abstract}

\section{Abbreviations}

BMSC: Bone marrow-derived mesenchymal stromal cell; IFN- $\Upsilon$ : Interferon gamma; IL-1ß: Interleukin-1 beta; LPS: Lipopolysaccharide; MSC: Mesenchymal stromal cell; OA: Osteoarthritis; TNF-a: Tumor necrosis factor alpha

\section{Acknowledgements}

The authors thank John O'Donnell and Holger Sondermann for their technical assistance and use of FPLC equipment for the purification of recombinant equine galectins. The authors acknowledge Kevin Packard and the Cornell Statistical Consulting Unit for assistance with statistical analysis.

\section{Funding}

Funding for this research was provided by the Harry M. Zweig Memorial Fund for Equine Research (AJN, HR), NIH grant number T32ODO1 1000 from the National Center for Research Resources (HLR) and the Grayson-Jockey Club Storm Cat Career Development Award (HLR). Imaging data was acquired in the Cornell BRC-Imaging Facility using the shared, NIH-funded (S100D010605) Spinning Disk Confocal. The study sponsors had no involvement in the study design, collection, analysis and interpretation of data; in the writing of the manuscript; and in the decision to submit the manuscript for publication.

\section{Availability of data and materials}

The datasets generated and/or analyzed during the current study will be available in the Genbank repository.

Equine galectin-1: https://www.ncbi.nlm.nih.gov/nuccore/ky264050 Equine galectin-3: https://www.ncbi.n/m.nih.gov/nuccore/ky264051 The qRT-PCR and migration datasets generated and/or analyzed during the current study are available from the corresponding author on reasonable request.

\section{Authors' contributions}

HLR contributed to the conception and design of the project; acquired, analyzed and interpreted data; drafted the article; and approved the final submitted version of the article. RMS, CRS, RPP, JST and JS contributed to collection of data; critically revised the article for important intellectual content; and approved the final submitted version of the article. MJP and AJN contributed to the design of the project, analysis and interpretation of data; critically revised the article for important intellectual content; and approved the final submitted version of the article. HLR and AJN obtained funding for the project. HLR and AJN take full responsibility for the integrity of the work as a whole, from inception to finished article. All authors read and approved the final manuscript. 


\section{Authors' information}

Not applicable.

\section{Ethics approval}

All animal and tissue harvesting protocols were approved by Cornell University's Institutional Animal Care and Use Committee (Protocol Number: 2011-0027).

\section{Consent for publication}

Not applicable.

\section{Competing interests}

The authors declare that they have no competing interests.

\section{Publisher's Note}

Springer Nature remains neutral with regard to jurisdictional claims in published maps and institutional affiliations.

\section{Author details}

'Department of Clinical Sciences, College of Veterinary Medicine, Cornell University, Ithaca, NY 14853, USA. ${ }^{2}$ Robert Frederick Smith School of Chemical and Biomolecular Engineering, Cornell University, Ithaca, NY 14853, USA.

Received: 30 March 2017 Revised: 8 August 2017 Accepted: 9 October 2017 Published online: 02 November 2017

\section{References}

1. Pittenger MF, Mackay AM, Beck SC, Jaiswal RK, Douglas R, Mosca JD, et al. Multilineage potential of adult human mesenchymal stem cells. Science. 1999;284:143-7.

2. Coleman CM, Curtin C, Barry FP, O'Flatharta C, Murphy JM. Mesenchymal stem cells and osteoarthritis: remedy or accomplice? Hum Gene Ther. 2010;21:1239-50.

3. Murphy JM, Fink DJ, Hunziker EB, Barry FP. Stem cell therapy in a caprine model of osteoarthritis. Arthritis Rheum. 2003;48:3464-74.

4. Prockop DJ, Youn OJ. Mesenchymal stem/stromal cells (MSCs): role as guardians of inflammation. Mol Ther. 2011;20:14-20.

5. Caplan Al. Why are MSCs therapeutic? New data: new insight. J Pathol. 2009;217:318-24.

6. Mcllwraith CW, Frisbie DD, Rodkey WG, Kisiday JD, Werpy NM, Kawcak CE, et al. Evaluation of intra-articular mesenchymal stem cells to augment healing of microfractured chondral defects. Arthroscopy. 2011;27:1552-61.

7. Mokbel AN, El Tookhy OS, Shamaa AA, Rashed LA, Sabry D, El Sayed AM. Homing and reparative effect of intra-articular injection of autologus mesenchymal stem cells in osteoarthritic animal model. BMC Musculoskelet Disord. 2011;12:259.

8. Wong KL, Lee KBL, Tai BC, Law P, Lee EH, Hui JHP. Injectable cultured bone marrow-derived mesenchymal stem cells in varus knees with cartilage defects undergoing high tibial osteotomy: a prospective, randomized controlled clinical trial with 2 years' follow-up. Arthroscopy. 2013;29:2020-8.

9. Tyndall A. Mesenchymal stromal cells and rheumatic disorders. Immunol Lett. 2015;168:1-7.

10. Carrade Holt DD, Wood JA, Granick JL, Walker NJ, Clark KC, Borjesson DL. Equine mesenchymal stem cells inhibit T cell proliferation through different mechanisms depending on tissue source. Stem Cells Dev. 2014;23:1258-65.

11. Meisel R, Zibert A, Laryea M, Göbel U, Däubener W, Dilloo D. Human bone marrow stromal cells inhibit allogeneic T-cell responses by indoleamine 2,3dioxygenase-mediated tryptophan degradation. Blood. 2004;103:4619-21.

12. Sala E, Genua M, Petti L, Anselmo A, Arena V, Cibella J, et al. Mesenchymal stem cells reduce colitis in mice via release of TSG6, independently of their localization to the intestine. Gastroenterology. 2015;149:163-76. e20.

13. Ortiz LA, Dutreil M, Fattman C, Pandey AC, Torres G, Go K, et al. Interleukin 1 receptor antagonist mediates the antiinflammatory and antifibrotic effect of mesenchymal stem cells during lung injury. Proc Natl Acad Sci U S A. 2007:104:11002-7.

14. Sioud M, Mobergslien A, Boudabous A, Fløisand Y. Evidence for the involvement of galectin-3 in mesenchymal stem cell suppression of allogeneic T-cell proliferation. Scand J Immunol. 2010;71:267-74.

15. Sioud M, Mobergslien A, Boudabous A, Fløisand Y. Mesenchymal stem cellmediated T cell suppression occurs through secreted galectins. Int J Oncol. 2011;38:385-90.
16. Liu GY, Xu Y, Li Y, Wang LH, Liu YJ, Zhu D. Secreted galectin-3 as a possible biomarker for the immunomodulatory potential of human umbilical cord mesenchymal stromal cells. Cytotherapy. 2013;15:1208-17.

17. Gieseke F, Böhringer J, Bussolari R, Dominici M, Handgretinger R, Müller I. Human multipotent mesenchymal stromal cells use galectin-1 to inhibit immune effector cells. Blood. 2010;116:3770-9.

18. Li C, Sun L, Zhang Y, Zhao J, Yao Z, Xu N, et al. Expression of Galectins in umbilical cord mesenchymal stem cells. Beijing Da Xue Xue Bao. 2013:45:452-7.

19. Yun SP, Lee S-J, Jung YH, Han HJ. Galectin-1 stimulates motility of human umbilical cord blood-derived mesenchymal stem cells by downregulation of smad2/3-dependent collagen 3/5 and upregulation of NF-KB-dependent fibronectin/laminin 5 expression. Cell Death Dis. 2014;5:e1049.

20. Sioud M. New insights into mesenchymal stromal cell-mediated T-cell suppression through galectins. Scand J Immunol. 2011;73:79-84.

21. Najar M, Raicevic G, Id Boufker H, Stamatopoulos B, De Bruyn C, Meuleman $\mathrm{N}$, et al. Modulated expression of adhesion molecules and galectin-1: role during mesenchymal stromal cell immunoregulatory functions. Exp Hematol. 2010;38:922-32.

22. Lepelletier $Y$, Lecourt $S$, Renand A, Arnulf B, Vanneaux V, Fermand J-P, et al. Galectin-1 and semaphorin-3A are two soluble factors conferring T-cell immunosuppression to bone marrow mesenchymal stem cell. Stem Cells Dev. 2010;19:1075-9.

23. Fajka-Boja R, Urbán VS, Szebeni GJ, Czibula Á, Blaskó A, Kriston-Pál É, et al. Galectin-1 is a local but not systemic immunomodulatory factor in mesenchymal stromal cells. Cytotherapy. 2016;18:360-70.

24. Dudics V, Kunstár A, Kovács J, Lakatos T, Géher P, Gömör B, et al. Chondrogenic potential of mesenchymal stem cells from patients with rheumatoid arthritis and osteoarthritis: measurements in a microculture system. Cells Tissues Organs. 2009;189:307-16.

25. Rabinovich GA, Baum LG, Tinari N, Paganelli R, Natoli C, Liu FT, et al. Galectins and their ligands: amplifiers, silencers or tuners of the inflammatory response? Trends Immunol. 2002;23:313-20.

26. Rabinovich GA, Rubinstein N, Toscano MA. Role of galectins in inflammatory and immunomodulatory processes. Biochim Biophys Acta. 2002;1572:274-84.

27. Baum LG, Blackall DP, Arias-Magallano S, Nanigian D, Uh SY, Browne JM, et al. Amelioration of graft versus host disease by galectin-1. Clin Immunol. 2003;109:295-307.

28. Liu SD, Lee S, La Cava A, Motran CC, Hahn BH, Miceli MC. Galectin-1induced down-regulation of T lymphocyte activation protects (NZB $\times$ NZW) F1 mice from lupus-like disease. Lupus. 2011;20:473-84.

29. Alturfan AA, Eralp L, Emekli N. Investigation of inflammatory and hemostatic parameters in female patients undergoing total knee arthroplasty surgery. Inflammation. 2008;31:414-21.

30. Ezzat MHM, El-Gammasy TMA, Shaheen KYA, Osman AOY. Elevated production of galectin-3 is correlated with juvenile idiopathic arthritis disease activity, severity, and progression. Int J Rheum Dis. 2011;14:345-52.

31. Harjacek M, Diaz-Cano S, De Miguel M, Wolfe H, Maldonado CA, Rabinovich GA. Expression of galectins-1 and -3 correlates with defective mononuclear cell apoptosis in patients with juvenile idiopathic arthritis. J Rheumatol. 2001;28:1914-22.

32. Hayashi J, Kihara M, Kato H, Nishimura T. A proteomic profile of synoviocyte lesions microdissected from formalin-fixed paraffin-embedded synovial tissues of rheumatoid arthritis. Clin Proteomics. 2015;12:20.

33. Reesink HL, Bonnevie ED, Liu S, Shurer CR, Hollander MJ, Bonassar LJ, et al. Galectin-3 binds to lubricin and reinforces the lubricating boundary layer of articular cartilage. Sci Rep. 2016;6:25463.

34. Guévremont M, Martel-Pelletier J, Boileau C, Liu F-T, Richard M, Fernandes JC, et al. Galectin-3 surface expression on human adult chondrocytes: a potential substrate for collagenase-3. Ann Rheum Dis. 2004;63:636-43.

35. Toegel S, Bieder D, André S, Kayser K, Walzer SM, Hobusch G, et al. Human osteoarthritic knee cartilage: fingerprinting of adhesion/growth-regulatory galectins in vitro and in situ indicates differential upregulation in severe degeneration. Histochem Cell Biol. 2014;142:373-88.

36. Ohshima S, Kuchen S, Seemayer CA, Kyburz D, Hirt A, Klinzing S, et al. Galectin 3 and its binding protein in rheumatoid arthritis. Arthritis Rheum. 2003:48:2788-95.

37. Iqbal AJ, Cooper D, Vugler A, Gittens BR, Moore A, Perretti M. Endogenous galectin-1 exerts tonic inhibition on experimental arthritis. J Immunol. 2013;191:171-7.

38. Rabinovich GA, Daly G, Dreja H, Tailor H, Riera CM, Hirabayashi J, et al. Recombinant galectin-1 and its genetic delivery suppress collagen-induced arthritis via T cell apoptosis. J Exp Med. 1999;190:385-98. 
39. Malik RKJ, Ghurye RR, Lawrence-Watt DJ, Stewart HJS. Galectin-1 stimulates monocyte chemotaxis via the p44/42 MAP kinase pathway and a pertussis toxin-sensitive pathway. Glycobiology. 2009;19:1402-7.

40. Auvynet C, Moreno S, Melchy E, Coronado-Martinez I, Montiel JL, AguilarDelfin I, et al. Galectin-1 promotes human neutrophil migration. Glycobiology. 2012;23:32-42.

41. Madrigal M, Rao KS, Riordan NH. A review of therapeutic effects of mesenchymal stem cell secretions and induction of secretory modification by different culture methods. J Transl Med. 2014;12:260.

42. Gieseke F, Kruchen A, Tzaribachev N, Bentzien F, Dominici M, Müller I. Proinflammatory stimuli induce galectin-9 in human mesenchymal stromal cells to suppress T-cell proliferation. Eur J Immunol. 2013;43:2741-9.

43. Barrachina L, Remacha AR, Romero A, Vázquez FJ, Albareda J, Prades M, et al. Effect of inflammatory environment on equine bone marrow derived mesenchymal stem cells immunogenicity and immunomodulatory properties. Vet Immunol Immunopathol. 2016;171:57-65.

44. Barrachina L, Remacha AR, Romero A, Vázquez FJ, Albareda J, Prades M, et al. Priming equine bone marrow-derived mesenchymal stem cells with proinflammatory cytokines: implications in immunomodulation-immunogenicity balance, cell viability, and differentiation potential. Stem Cells Dev. 2017;26:15-24.

45. Succar P, Medynskyj M, Breen EJ, Batterham T, Molloy MP, Herbert BR. Priming adipose-derived mesenchymal stem cells with hyaluronan alters growth kinetics and increases attachment to articular cartilage. Stem Cells Int. 2016;2016:1-13.

46. Maerz T, Fleischer M, Newton MD, Davidson A, Salisbury M, Altman P, et al. Acute mobilization and migration of bone marrow-derived stem cells following anterior cruciate ligament rupture. Osteoarthr Cartil. 2017;25:1335-44.

47. Fortier LA, Nixon AJ, Williams J, Cable CS. Isolation and chondrocytic differentiation of equine bone marrow-derived mesenchymal stem cells. Am J Vet Res. 1998;59:1182-7.

48. Saxer RA, Bent SJ, Brower-Toland BD, Mi Z, Robbins PD, Evans CH, et al. Gene mediated insulin-like growth factor-I delivery to the synovium. J Orthop Res. 2001;19:759-67.

49. Nixon AJ, Lust G, Vernier-Singer M. Isolation, propagation, and cryopreservation of equine articular chondrocytes. Am J Vet Res. 1992;53:2364-70.

50. Kamm JL, Nixon AJ, Witte TH. Cytokine and catabolic enzyme expression in synovium, synovial fluid and articular cartilage of naturally osteoarthritic equine carpi. Equine Vet J. 2010;42:693-9.

51. Pace KE, Hahn HP, Baum LG. Preparation of recombinant human galectin-1 and use in T-cell death assays. Methods Enzymol. 2003;363:499-518.

52. Gibbons JD, Chakraborti S. Measures of association in multiple classifications. In: Owen DB, editor. Nonparametric statistical inference. 4th ed. New York: Marcel Dekker, Inc; 2003. p. 450-93.

53. Dasuri K, Antonovici M, Chen K, Wong K, Standing K, Ens W, et al. The synovial proteome: analysis of fibroblast-like synoviocytes. Arthritis Res Ther. 2004;6:R161-8.

54. Toegel S, Bieder D, André S, Altmann F, Walzer SM, Kaltner H, et al. Glycophenotyping of osteoarthritic cartilage and chondrocytes by RT-qPCR, mass spectrometry, histochemistry with plant/human lectins and lectin localization with a glycoprotein. Arthritis Res Ther. 2013;15:R147.

55. Pabst M, Wu SQ, Grass J, Kolb A, Chiari C, Viernstein H, et al. IL-1 $\beta$ and TNFa alter the glycophenotype of primary human chondrocytes in vitro. Carbohydr Res. 2010;345:1389-93.

56. Wang C-R, Shiau A-L, Chen S-Y, Cheng Z-S, Li Y-T, Lee C-H, et al. Intraarticular lentivirus-mediated delivery of galectin-3 shRNA and galectin-1 gene ameliorates collagen-induced arthritis. Gene Ther. 2010;17:1225-33.

57. Xibillé-Friedmann D, Bustos Rivera-Bahena C, Rojas-Serrano J, Burgos-Vargas R, Montiel-Hernández J-L. A decrease in galectin-1 (Gal-1) levels correlates with an increase in anti-Gal-1 antibodies at the synovial level in patients with rheumatoid arthritis. Scand J Rheumatol. 2013;42:102-7.

58. Wang J, Xia J, Zhang F, Shi Y, Wu Y, Pu H, et al. Galectin-1-secreting neural stem cells elicit long-term neuroprotection against ischemic brain injury. Sci Rep. 2015;5:9621

59. Lundberg E, Fagerberg L, Klevebring D, Matic I, Geiger T, Cox J, et al. Defining the transcriptome and proteome in three functionally different human cell lines. Mol Syst Biol. 2010;6:450

60. Schwanhäusser B, Busse D, Li N, Dittmar G, Schuchhardt J, Wolf J, et al. Global quantification of mammalian gene expression control. Nature. 2011;473:337-42.

61. Neidhart M, Zaucke F, von Knoch R, Jüngel A, Michel BA, Gay RE, et al. Galectin-3 is induced in rheumatoid arthritis synovial fibroblasts after adhesion to cartilage oligomeric matrix protein. Ann Rheum Dis. 2005;64:419-24.
62. Barrachina L, Remacha AR, Romero A, Vázquez FJ, Albareda J, Prades M, et al. Inflammation affects the viability and plasticity of equine mesenchymal stem cells: possible implications in intra-articular treatments. J Vet Sci. 2017;18:39.

63. Matarrese P, Fusco O, Tinari N, Natoli C, Liu FT, Semeraro ML, et al. Galectin3 overexpression protects from apoptosis by improving cell adhesion properties. Int J Cancer. 2000;85:545-54.

64. Friedrichs J, Manninen A, Muller DJ, Helenius J. Galectin-3 regulates integrin alpha2beta1-mediated adhesion to collagen-I and -IV. J Biol Chem. 2008;283:32264-72.

65. Priglinger CS, Szober CM, Priglinger SG, Merl J, Euler KN, Kernt M, et al. Galectin-3 induces clustering of CD147 and integrin- $\beta 1$ transmembrane glycoprotein receptors on the RPE cell surface. PLoS One. 2013;8:e70011.

66. Seguin L, Kato S, Franovic A, Camargo MF, Lesperance J, Elliott KC, et al. An integrin $\beta_{3}$-KRAS-RalB complex drives tumour stemness and resistance to EGFR inhibition. Nat Cell Biol. 2014;16:457-68.

67. Chiu LH, Yeh TS, Huang HM, Leu SJ, Yang CB, Tsai YH. Diverse effects of type II collagen on osteogenic and adipogenic differentiation of mesenchymal stem cells. J Cell Physiol. 2012;227:2412-20.

68. Krishna OD, Jha AK, Jia X, Kiick KL. Integrin-mediated adhesion and proliferation of human MSCs elicited by a hydroxyproline-lacking, collagenlike peptide. Biomaterials. 2011;32:6412-24.

69. Conget PA, Minguell JJ. Phenotypical and functional properties of human bone marrow mesenchymal progenitor cells. J Cell Physiol. 1999;181:67-73.

70. Ochieng J, Warfield P, Green-Jarvis B, Fentie I. Galectin-3 regulates the adhesive interaction between breast carcinoma cells and elastin. J Cell Biochem. 1999;75:505-14.

71. Panjwani N. Role of galectins in re-epithelialization of wounds. Ann Transl Med. 2014;2:89

72. Lin YT, Chen JS, Wu MH, Hsieh IS, Liang CH, Hsu CL, et al. Galectin-1 accelerates wound healing by regulating the Neuropilin-1/Smad3/NOX4 pathway and ROS production in myofibroblasts. J Invest Dermatol. 2015;135:258-68.

73. Fulcher JA, Hashimi ST, Levroney EL, Pang M, Gurney KB, Baum LG, et al. Galectin-1-matured human monocyte-derived dendritic cells have enhanced migration through extracellular matrix. J Immunol. 2006;177:216-26.

\section{Submit your next manuscript to BioMed Central and we will help you at every step:}

- We accept pre-submission inquiries

- Our selector tool helps you to find the most relevant journal

- We provide round the clock customer support

- Convenient online submission

- Thorough peer review

- Inclusion in PubMed and all major indexing services

- Maximum visibility for your research

Submit your manuscript at www.biomedcentral.com/submit
Biomed Central 